DOI 10.4467/2543733XSSB.16.003.6245

PAWEŁ F. NOWAKOWSKI

Akademia Ignatianum w Krakowie

\title{
CECHY HUSYCKICH POLEMIK RELIGIJNYCH - ZARYS ZAGADNIENIA
}

\begin{abstract}
Słowa kluczowe: polemika religijna, husytyzm, Antychryst, manipulacje tekstem
\end{abstract}
\section{Wprowadzenie do zagadnienia}

Spalenie Jana Husa na stosie w Konstancji 6 lipca 1415 r. miało symbolicznie kończyć kontrowersję doktrynalną, wywołaną przez jego pisma i kazania, do których odnosili się badający jego sprawę członkowie soboru. Reakcja czeskich zwolenników kaznodziei, oburzenie na wyrok soborowy, które podzielała znacząca część możnych w Królestwie Czeskim, oraz niepokoje społeczne doprowadziły jednak do wybuchu rewolucji husyckiej, a wraz z nią do dalszego wzrostu emocji religijnych ${ }^{1}$. Innym przejawem tego napięcia było nieustanne nawoływanie do dyskusji z przeciwnikami ${ }^{2}$. Zwolennicy mniej i bardziej radykalnych propozycji reformatorskich chcieli udowadniać prawdziwość swoich tez, przede wszystkim wobec przedstawicieli hierarchii kościelnej, odpowiedzialnych za potępienie tez Husa. Niemniej bardzo szybko okazało się, że spoiwo, jakim jest postać spalonego myśliciela, jest niewystarczające wobec zróżnicowania poglądów samych czeskich reformatorów, co sprawiło, że dyskutowali nie tylko reformatorzy z przedstawicielami Kościoła katolickiego, ale i reprezentanci poszczególnych nurtów reformatorskich między sobą. $\mathrm{W}$ ciągu lat pomiędzy rozpoczynającą rewolucję husycką defenestracją praską z $1419 \mathrm{r}$. a śmiercią Jerzego z Podiebradów - husyckiego króla oraz Jana Rokycany, duchowego

${ }^{1}$ Atmosferę wokół sprawy Husa i przyjęcia jego wyroku pokazują m.in. F. Š m a h e 1, Jan Hus. Život a dílo, Praha 2013, s. 221 i n.; E. K a n tů r k o v a, Jan Hus, Praha 2008, s. 387-390; F. Š m a h e 1, Život a dílo Jeronýma Pražského, Praha 2010, s. 81; T. F u d g e, The Trial of Jan Hus. Medieval Heresy and Criminal Procedure, Oxford 2013, s. 296 i n.; A. P a n e r, Jan Hus, Kraków 2002, s. 83-85. Najbardziej znamienną wśród pierwszych reakcji jest list szlachty czeskiej i morawskiej w proteście przeciw spaleniu Jana Husa, zob. Stižný list české a moravské šlechty proti upáleni mistra Jana Husa, red. P. Čornej, A. Knápek, L. Macek, P. Rous, Okrouhlice 2015.

2 Páni a Pražané všem Čechiom, [w:] Husitské manifesty, ed. A. Molnár, Praha 1980, s. 69-70; Protisatirický husitský manifest, [w:] Husitské manifesty..., s. 75; Manifest Starého a Nového Města Pražského, [w:] Husitské manifesty..., s. 118-119. 
przywódcy utrakwistów w 1471 r., rozwinięto cały szereg zagadnień, które powracały nieraz w sporych odstępach czasowych. Pojawiały się nowe nurty czeskiej reformy i wygasały wcześniej istniejące, co rodziło pytania i problemy, z którymi mierzyli się dysputanci. W pewnym zarysie, mając na uwadze syntetyczny ogląd zagadnienia, warto przedstawić cechy i okoliczności religijnych dysput tego okresu.

\section{Formy polemik}

W ramach polemik dążono oczywiście do bezpośrednich rozmów, które umożliwiałyby natychmiastową lub niemal natychmiastową wymianę zdań. Tego typu spotkania miały miejsce zarówno na początku omawianego okresu, jak i u jego schyłku. Niezwykle istotna dla późniejszego rozwoju nurtów czeskiej reformy okazała się dysputa $\mathrm{w}$ domu Petra Zmrzlíka, do której doszło w grudniu 1420 r. ${ }^{3}$ Jej przebieg, znany z kroniki Wawrzyńca z Brzezowej, dowodzi, że wówczas po raz pierwszy sami husyci, zarówno radykalni jak i umiarkowani, zorientowali się, jak bardzo istotne jest miejsce obrad, sposób ich prowadzenia i przygotowanie. Radykałowie, zarzuceni wówczas przez stronę umiarkowaną listą 72 błędów dostrzeżonych w ich naukach, odebrali debatę jako atak, na którego odparcie nie mieli możliwości się przygotować ${ }^{4}$.

Doświadczenie wyniesione z dyskusji w domu Zmrzlika skutkowało dbałością o przygotowania do dyskusji z soborem zapewne w nie mniejszym stopniu niż pamięć o losie Jana Husa w Konstancji. W związku z tym formę prowadzenia debaty i zasady dotyczące pobytu i bezpieczeństwa delegacji czeskiej ustalono już w czasie rozmów w Chebie w 1432 r. ${ }^{5} \mathrm{~W}$ czasie samych obrad, toczonych w Bazylei od stycznia do kwietnia 1433 r., stosowano się do wcześniejszych ustaleń. W naprzemiennych wystąpieniach delegatów czeskich i przedstawicieli soborowych pilnowano spokoju i trzymania się uzgodnionych zagadnień. Husytom zapewniono bezpieczeństwo i niezakłócony pobyt ${ }^{6}$. Strona soborowa potrafiła jednak moderować nastroje, w czym celował kardynał Julian Cesarini, tworząc pewien schemat postępowania. Każde wzburzenie, do którego dochodziło na sali podczas obrad, było przez niego uspokajane, a następnie podejmowano jakąś próbę rozmów kuluarowych. Cesarini szybko zorientował się też, jakie niespójności kryją się w stanowisku samej delegacji czeskiej ${ }^{7}$.

${ }^{3}$ O samym gospodarzu dysputy, zob. A. S e d lá č e k, Zmrzlik ze Svojšína, [w:] Ottův Slovník Naučný, t. 27, Praha 1908, s. 653.

${ }^{4}$ Vavřinec z Březove, Kronika husitská, [w:] Fontes Rerum Bohemicarum, t. V, ed. J. Goll, Praha 1893, s. 454-462. O rodzajach błędów zob.: S. B y li n a, Na skraju lewicy husyckiej, Warszawa 2005, s. 120.

5 Przebieg negocjacji opracowano w 550. rocznicę wydarzenia, a wyniki badań wydano w zbiorze Soudce smluvený v Chebu. Sborník př́spěvků přednesených na symposiu k 550. výrocí, red. J. J a náč e k, Cheb 1982.

${ }^{6}$ Zobowiązywały do tego uzgodnione punkty, zwłaszcza p. 6, mówiący o tym, że żadne prawa, dekrety ani kanony, zwłaszcza z soborów w Konstancji i Sienie, nie mogą być użyte przeciwko delegacji czeskiej, zob. Johannis de Ragusio tractatus quomodo Bohemi reducti sunt ad unitatem Ecclesiae, [w:] Monumenta conciliorum generalium seculi decimi quinti, t. I, ed. F. Palacký, Vindobonae 1857, s. 220.

7 Przebieg obrad szczegółowo zrelacjonował uczestnik czeskiej delegacji, zob. Deník táborského kněze o jednani Čechů na koncilu basilejském z roku 1433, [w:] Ze zpráv a kronik doby husitské, př. F. Heřmanský, ed. I. Hlaváček, Praha 1981, s. 317-419. Opracowanie oparte na czeskiej relacji z uwzględnieniem niektórych materiałów strony soborowej przygotował A. Krch ňák, Čechové na basilejském sněmu, Svitavy 1997. 
Nagromadzenie negatywnych doświadczeń z wcześniejszych dysput oraz porozumienia, w które weszły strona utrakwistyczna i sobór, a także zbrojny konflikt między stroną umiarkowaną a radykałami, utrudniały późniejsze rozmowy. Niemniej lata 1443-1444 przyniosły próbę takiej dysputy, w której strona umiarkowana miała przewagę ${ }^{8}$. Celem utrakwistów było de facto zmarginalizowanie osłabionych radykałów i wypracowanie formuły potępiającej ich poglądy na Eucharystię, co też się stało.

Do ciekawych przykładów polemik korespondencyjnych można zaliczyć wymianę listów między Janem Kapistranem a husytami w okresie jego misji morawskiej w $1451 \mathrm{r} .{ }^{9}$ Ponieważ zakonnik nie został dopuszczony do swobodnego głoszenia kazań na terenie Czech, korespondencyjnie próbował uzyskać zgodę na swoją misję i jednocześnie prowadził ideowy spór z utrakwistami czeskimi. O ile wymiana listów między Janem Kapistranem a Janem z Borotína, Jerzym z Podiebradów i in. należy do klasycznej formy polemik korespondencyjnych, o tyle specyficzną jej formą są bez wątpienia manifesty $z$ okresu rewolucji husyckiej, a więc $z$ lat 1420-1431. Listy o charakterze propagandowym, ale i apologetycznym kierowane były zwykle do adresata zbiorowego - do Czechów, wojska miśnieńskiego etc ${ }^{10}$.

Wśród polemik będących pojedynkami słownymi wybitnych postaci warto zwrócić zwłaszcza uwagę na rozmowę, którą podczas wizyty na Taborze w $1451 \mathrm{r}^{11} \mathrm{z}$ głównymi ideologami słabego już wówczas ośrodka radykałów prowadził Eneasz Sylwiusz Piccolomini (późniejszy Pius II). Wspomniany dyskurs znany jest z relacji Piccolominiego ${ }^{12}$. Bogatszym źródłowo wydarzeniem do zbadania jest natomiast dysputa, jaką na początku 1465 r. wobec króla Jerzego z Podiebradów toczyli utrakwistyczny arcybiskup Pragi Jan Rokycana i dwóch katolików: administrator diecezji praskiej, Hilary Litoměřícký oraz Wacław Kř́žzanovský. Obie strony opracowały traktaty będące pokłosiem dyskusji, co pozwala wniknąc w specyfikę tego starcia ideowego ${ }^{13}$.

\footnotetext{
${ }^{8}$ Opracowanie i źródła do dysput tego okresu wydał Z. Nejedlý, Prameny $k$ synodám strany pražské a táborské v létech 1441-1444, Praha 1900.

${ }^{9}$ Przebieg misji został opracowany m.in. przez J. Ho fer, Johannes Kapistran. Ein Leben im Kapf um die Reform der Kirche, t. II, Romae 1964, rozdz. 10 i 12; A. L i s o w s k a, Antyhusycka misja Jana Kapistrana na Śląsku, [w:] Bernardyni na Ślasku w późnym średniowieczu, red. J. K o s to w s k i, Wrocław 2005, s. 51-63.

${ }^{10}$ Zbiór manifestów z różnych okresów został wydany drukiem: Husitské manifesty, ed. A. Moln ár, Praha 1980.

${ }^{11}$ O misji środkowoeuropejskiej Piccolominiego i jej okolicznościach zob. J. S m ołu ch a, Polityka kurii rzymskiej za pontyfikatu Piusa II (1458-1464) wobec Czech i krajów sąsiednich. Z dziejów dyplomacji papieskiej w XV wieku, Kraków 2008, s. 88-94. O samej wizycie na Taborze zob. F. P a la c ký, Dějiny národu českého w Čechách a w Morawě dle půwodnich pramenůw, t. IV/1, Praha 1857, s. 233 i nn.; R. U rb á n e k, České dějiny, t. III/2 (Věk poděbradský), Praha 1930, s. 527-533; G. Vo ig t, Enea Silvio de' Piccolomini als Papst Pius der Zweite und sein Zeitalter, Bd. 2, Berlin 1862, s. 26-29; H. K a m in s ky, Pius Aeneas among the Taborites, „Church History”, 1959, v. 28, nr 3, s. 281-309; P. Č o r n e j, M. B a r t lo vá, Velké dějiny zemi Koruny České, t. VI: 1437-1526, Paseka-Praha-Litomys1 2007, s. 107-109 i in.

${ }^{12}$ Der Briefwechsel des Eneas Silvius Piccolomini, v. III, ed. R. Wolk a n, Fontes Rerum Austriacarum, Bd. 68, Wien 1918, s. 22-57.

${ }^{13}$ Hilarii Litomericensis, s. Ecclesiae Pragensis decani, Disputatio cum Ioanne Rokyczana coram Georgio, rege Bohemiae, per quinque dies habita anno 1465, ed. B. V. S tr a h 1, Pragae 1775; Traktát Mistra Jana Rokycany o prijímáni krve (české zpracování latinského traktátu Contra sex proposiciones frivolas doctorum apostatarum), ed. F. Š i m e k, Praha 1941.
} 


\section{Stosunek do tradycji}

Głównymi tematami polemik były oczywiście poglądy eucharystyczne oraz postulat udzielania komunii pod dwiema postaciami zarówno dorosłym wiernym, jak i dzieciom. Zagadnieniom, z których pierwsze dominowało w sporach między różnymi nurtami reformatorskimi, natomiast drugie stanowiło sztandarowy temat dysput husytów z katolikami, poświęcono wiele uwagi w literaturze - $\mathrm{i}$ wciąż jako niezwykle obszerne pole problemów badawczych inspirują one do wnikliwych studiów ${ }^{14}$. Niezależnie od tych dominujących tematów, i niejako przy okazji, w dysputach pojawiały się też ciekawe motywy, niebędące właściwym przedmiotem sporu. Ich dostrzeżenie pozwala uchwycić niuanse i specyfikę toczonych wówczas polemik.

W wymianie korespondencji między Janem z Borotína i Janem Kapistranem można zauważyć formułę erystyczną, która pokazuje stosunek umiarkowanych utrakwistów z kręgu uniwersyteckiego do europejskiej tradycji antycznej ${ }^{15}$. Jan z Borotína, lekarz i zwolennik trendów humanistycznych, w nieco złośliwy sposób zarzucił Kapistranowi melancholię, przypominając, że jest traktowana jak choroba duszy. Chcąc niejako złagodzić złośliwość przytyku, powołał się przy tym na Arystotelesa i przykłady mitologiczne wielkich mężów, którzy byli dotknięci tą przypadłością ${ }^{16}$. Rzeczywiście, Stagiryta w swoim dziele Problemata przytoczył m.in. przykłady Ajaksa i Belleforonta, których melancholia doprowadziła do zguby ${ }^{17}$. Kapistran podjął w sposób żartobliwy wyzwanie, przyznając się raczej do bycia cholerykiem oraz podważając wydaną zaocznie diagnozę.

Innym motywem jest nieporuszany bezpośrednio stosunek do tradycji kościelnej, której konstytutywnym elementem już od czasów Husa było odniesienie się do władzy papieża, negowanej bądź warunkowanej pełnieniem jej w sposób należyty i świątobliwy. Problem uznania papieża był jednak jednym $\mathrm{z}$ wielu aspektów, które mogły być poddawane krytyce w oparciu o motyw działalności Antychrysta. To jedno z najistotniejszych dla rewolucji husyckiej pojęć, choć nie było przedmiotem zażartych polemik, przewija się przez wiele traktatów i listów ${ }^{18}$. Husyci czerpali przekonanie o działalności Antychrysta jeszcze z pism myślicieli poprzedzających Husa - Jana Milíča z Kroměřža i Macieja z Janova ${ }^{19}$.

14 Jednym z najciekawszych i najdokładniejszych opracowań ostatnich lat dla okresu wczesnego utrakwizmu i lat rewolucji jest bez wątpienia D. C o u fa 1, Polemika o kalich mezi teologii a politikou 1414-1431, Kalich 2012.

15 Zob. Jan z Borotína, Ottův Slovník Naučný, t. 4, Praha 1891, s. 401.

${ }^{16}$ List opublikowany w F. Wa lo u c h, Žiwotopis swatého Jana Kapistrana, Brno 1858, s. 791-792.

17 Ar is t o t le, Problems, tt. W. S. Hett, t. 2, London-Cambridge MA 1957, s. 154-157 (wydanie dwujęzyczne grecko-angielskie).

18 A. Mi chále k, Antikrist - kličové slovo v jazyce doby husitské, „Husitsky Tábor”, 1981, v. 4, s. 110112; P. C e r m a n o á, Jakoubkův a Biskupcův Výklad na Apokalypsu. Porovnání s di̊razem na interpretaci antikristovského mýtu, [w:] Jakoubek ze Střibra. Texty a jejich působeni, ed. O. H a l a m a, P. S o u k u p, Praha 2006, s. 209-227; P. L i b i c h o vá C e r m a nová, Antichristus avarus contra pauperes Christi. Chudoba a její vyznam v apokaliptickém diskurzu, [w:] Colloquia mediaevalia Pragnesia, t. VI: Zbožnost středověku, ed. M. N o d 1, Praha 2007, s. 111-134; e a de m, Gog a Magog: lid z konce světa a věků v husitství, [w:] Zrození mýtu. Dva životy husitské epochy. K počtě Petra Čorneje, ed. R. N o v o t ný, P. Š a m a l, Paseka-Praha-Litomyšl 2011, s. 230-243, $\mathrm{i}$ in.; P. N e j e d lý, K vývoji substantiva Antikrist(us) ve staročeské slovní zásobě, [w:] Zrození mýtu..., s. 285-298.

${ }_{19}$ Milicii Libellus de Antichristo, [w:] Matěj z Janova, Regulae Veteris et Novi Testamenti, sv. 3, ed. V. Kybal, Innsbruck 1911, s. 368-381. Wersja czeska: J. Milíč z Kroměřiža, Spisek o Antikristovi, [w:] Milič z Kroměříže, Poslání papeži Urbanu V. Spisek o Antikristovi, ed. F. Loskot, Praha 1948, s. 18-27; Matěj z J anova, Regulae Veteris et Novi Testamenti, sv. 3, ed. V. Kybal, Innsbruck 1911. 
Kolejni autorzy, jak Piotr Chelczycki, opracowali osobne traktaty poświęcone jego działaniu w świecie i Kościele, a inni, jak Jakubek ze Střibra, bardzo mocno podkreślali w swoich pismach jego rolę ${ }^{20}$. Pojęcie Antychrysta okazało się motywem, który wyznaczał stosunek do tradycji kościelnej. Nie ma tu jasnej cezury, nie ma też jednej doktryny, zjawiska ocenia się przez pryzmat tego, w jakim stopniu mogły być poddane wpływowi Antychrysta, bądź zostać po prostu jego wytworami.

Nieco światła na pole działalności Antychrysta rzuca stosunek do Donacji Konstantyna, choć w czasie rozwoju myśli husyckiej był to koncept już formalnie oceniany negatywnie $^{21}$. Nie tylko Lorenzo Valla poddał Donację krytyce historycznej, nad jej autentycznością pochylał się również Eneasz Sylwiusz Piccolomini, który z Czechami miał styczność i, jak wspomniano, polemizował z husytami na Taborze. Niemniej w całym okresie husyckim widać u poszczególnych autorów przywiązanie do idei Donacji Konstantyna $^{22}$, powszechnie traktowanej jako zdarzenie, od którego rozpoczęło się ,wlewanie jadu do Kościoła", a więc psucie instytucji kościelnych i zwodzenie dokonywane przez Antychrysta $^{23}$.

Z tych względów w przypadku powoływania się na autorytety teologiczne nie można wyróżnić żadnej cezury. Poza samymi księgami biblijnymi, wszystkie strony polemik opierają się na dokumentach kościelnych, także pismach Ojców Kościoła i późniejszych teologów, w tym średniowiecznych. Dominuje wszakże zasada, którą wyraził w jednym z traktatów Jan Rokycana, mianowicie dawania pierwszeństwa dawnym pisarzom przed „novakami” ${ }^{24}$. W okresie przygotowań do rokowań bazylejskich w Chebie wypracowano metodę argumentacji, którą stosowano później w czasie omawiania poszczególnych kwestii na soborze. Był to tzw. „soudce chebský”, a więc układ argumentów zgodny z ich hierarchią i chronologią, począwszy od tekstów biblijnych, przez pisma Ojców Kościoła itd ${ }^{25}$.

W czasie rozmów z husytami w Taborze, Eneasz Sylwiusz Piccolomini wytknął oponentom jeszcze jedną z cech, które charakteryzowały stosunek do tradycji kościelnej, obecną zarówno w codzienności, jak i w polemikach. Podkreślając ich sympatię do chrześcijaństwa wschodniego, gdzie przechowano zwyczaj podawania komunii pod dwie-

${ }^{20}$ P. Chelč i c ký, O šelmě a obraze jejím, [w:] Čitanka Petra Chelčického, ed. K. J. Obrátil, Brno 1925, s. 107-126; idem, Tuto se již počiná jíná řeč o šelmě a obraze jejím, [w:] Čitanka Petra Chelčického..., s. 126-129; J a k o u be k ze S tř i bra, Výklad na zjevenie sv. Jana, ed. F. Šimek, dil I-II, Praha 1932-1933, passim.

${ }^{21}$ Szerzej na ten temat zob. P. K r a s, Donacja Konstantyna-legenda w stużbie polityki papieskiej, ,Studia Mediaevalia Bohemica", 2011, v. 3, nr 1, s. 7-32.

${ }^{22}$ J. Hu s, O Kościele, tł. K. Moskal, Lublin 2007, s. 128; J. H u s, Responsum M. J. Hus ad articulos 42. a M. Stephano de Paleč commissariis concilii contra eum propositos, [w:] Documenta Mag. Joannis Hus, vitam, doctrinam, causam in Constantiensi concilio actam et controversias de religione in Bohemia annis 1403-1415, ed. F. Palacký, Pragae 1869, s. 211; J a k o u be k ze S tř ibra, Výklad na zjevenie sv. Jana..., dil I, s. 329; Manifest Starého a Nového Města Pražského, [w:] Husitské manifesty... s. 112; List z celé země české, [w:] Husitské manifesty..., s. 187; J an z R abšte jn a, Dialogus, ed. B. Ryba, Praha 1946, s. 74-76 i in.

${ }^{23}$ Termin ,jad wlany do Kościoła" przejęty został przez husytów i stosowany powszechnie, np. w manifeście z 1431 r.: List z celé země české, [w:] Husitské manifesty..., s. 187-188.

${ }^{24}$ Traktát Mistra Jana Rokycany o prijímáni krve (české zpracováni latinského traktátu Contra sex proposiciones frivolas doctorum apostatarum), ed. F. Š i m e k, Praha 1941, s. 45.

${ }_{25}$ Zasada znalazła się w punkcie 7 porozumień chebskich: Johannis de Ragusio tractatus quomodo Bohemi reducti sunt ad unitatem Ecclesiae, [w:] Monumenta conciliorum generalium seculi decimi quinti, t. I, ed. F. P a l a c ký, Vindobonae 1857, s. 220; A. Molná r, Chebský soudce, [w:] Soudce smluvený v Chebu. Sborník př́spěvků přednesených na symposiu k 550. výrocí, red. J. Janáček, Cheb 1982, s. 9-35. 
ma postaciami wszystkim wiernym, Piccolomini zwrócił uwagę, że husytów znamionuje wybiórczość w przyjmowaniu różnych elementów wiary z tradycji łacińskiej lub greckiej. Przywołał przy tym zdanie z Listu do Laodycei, znajdującego się w Apokalipsie, sugerując, by byli albo gorący, albo zimni (Ap 3, 15-16) ${ }^{26}$. W istocie uwaga przyszłego papieża dobrze podsumowywała stosunek husytów do tradycji w jej różnych wymiarach.

\section{Zabiegi manipulacyjne}

Podczas dysput i polemik nie obyło się bez rozmaitych, dotyczących różnych sfer manipulacji. Dla przykładu utrakwista umiarkowanych poglądów, Jan Přibram, oskarżany był przez swoich oponentów o wyrywanie z kontekstu wypowiedzi i zmianę znaczenia przywoływanych porównań. W rezultacie podczas ideowych sporów w latach 1443-1444 radykałowie nie chcieli zgodzić się na dyskusje z Přibramem, jeśli wcześniej nie mieli zagwarantowanego wystarczającego czasu na weryfikację i odpowiedź w poruszanych kwestiach. Opinia ta nie była bezpodstawna, co może pokazać jeden z przykładów. Přibram powoływał się na zasłyszane przed ponad dwudziestu laty kazanie, w którym kaznodzieja miał przekonywać, iż lepiej jest oddawać cześć kretom niż konsekrowanej hostiii ${ }^{27}$. Jednak używając tego obrazu jako argumentu na bezbożność radykałów, ukrył właściwe pochodzenie i znaczenie przykładu. Stosowna uwaga znajduje się w traktacie Wycliffe'a De Eucharistia i jest oparta na wnioskowaniu filozoficznym ${ }^{28}$. Angielski teolog, który negował transsubstancjację, przekonywał, że jeśli w czasie konsekracji dochodzi do anihilacji substancji chleba, to wówczas widoczny chleb jest pozbawiony substancji. Gdy więc w dawnych czasach poganie oddawali cześć kretom i innym stworzeniom, byli w o tyle lepszej sytuacji, że oddawali cześć bytowi istniejącemu, niepozbawionemu substancji, a zatem na wyższym poziomie bytowym niż konsekrowana hostia. Wyciąganie $\mathrm{z}$ tego przykładu wniosku, jakoby taboryci uważali, że lepiej jest się „kłaniać kretom niż Ciału Bożemu", jest nadużyciem i przeinaczeniem znaczenia przykładu.

Innym sposobem manipulowania było wyrywanie wypowiedzi z kontekstu, przy czym zabieg ten stosowano, nie oszczędzając nawet traktatów teologicznych. Jeden z przykładów obrony komunii pod dwiema postaciami i konieczności komunii do zbawienia pokazuje to całkiem dobrze. W Traktácie o prijímání krve Jan Rokycana skorzystał z tekstu XIV-wiecznego teologa, Mikołaja z Liry. Przytaczając bez przeinaczeń fragment dzieła Mikołaja, uzyskał argument za swoją tezą ${ }^{29}$. Nie odnotował jednak, że w dalszej części cytowanego traktatu, zaledwie kilka stronic dalej, Mikołaj uzasadnia, iż praktyka Kościoła $\mathrm{w}$ tej mierze jest w pełni poprawna i wówczas argumentuje w jej obronie, co jest zupełnie sprzeczne z poglądem husyckim ${ }^{30}$.

Ewidentną próbą podfałszowania tekstu są natomiast przykłady zawarte w traktacie Prokopa z Pilzna o komunii dzieci, opracowanym na potrzeby dyskusji na ten temat

\footnotetext{
${ }^{26}$ Der Briefwechsel des Eneas Silvius Piccolomini..., s. 48-49.

${ }^{27}$ List M. Jana Příbrama p. Jakubovi (z Vřesovic) o jednání na synodě Kutnohorské, 21 VII 1443, [w:] Z. N ej e dlý, Prameny k synodám..., s. 43;

${ }^{28}$ I. Wy c liffe, De Eucharistia tractatus maior, ed. I. Loserth, London 1892, s. 20.

29 Traktát Mistra Jana Rokycany o prijímáni krve..., s. 22.

${ }^{30} \mathrm{~N}$ icolaus de Lyra, Postilla super totam Bibliam, ks. 5, ed. O. Scotus, Venetia 1488, s. 70 (nienumerowana).
} 
z soborem bazylejskim. Uzasadniając stanowisko husyckie, autor powołuje się na Summę Teologiczna św. Tomasza z Akwinu. Pragnąc udowodnić tezę o konieczności przyjmowania komunii do zbawienia, pozwala sobie na pominięcie istotnych słów, a nawet zdań z cytowanego passusu Summy Teologicznej, które temu przeczą. Jest to niewątpliwie zabieg celowy, nie można go uznać ani za omyłkę, ani zaledwie wyrwanie z kontekstu.

Tego typu praktyka jest dobrze widoczna na jednym z przykładów, gdzie właściwe zdanie św. Tomasza w brzmieniu:

Et ideo perceptio Baptismi est necessaria ad inchoandam spiritualem vitam, perceptio autem Eucharistiae est necessaria ad consummandam ipsam, non ad hoc quod simpliciter habeatur, sed sufficit eam habere in voto, sicut et finis habetur in desiderio et intentione ${ }^{31}-$

podano w rękopisie traktatu Prokopa w wersji:

Et ideo percepcio baptismi est necessaria ad inchoandum spiritualem vitam, percepcio autem Eukaristie est necessaria ad consummandam ipsam ${ }^{32}$.

W ten sposób zmieniono istotnie sens wypowiedzi Tomaszowej. Tam, gdzie Akwinata podkreślał, że sama intencja przyjęcia Eucharystii wystarczy do wypełnienia życia duchowego, husycki teolog zmienił sens. W jego wersji właściwe przyjęcie Eucharystii jest niezbędne do wypełnienia życia duchowego. Fałszerstwo wsparło pogląd utrakwistów o konieczności przyjmowania Eucharystii do zbawienia.

\section{Podsumowanie}

Rys cech husyckich polemik religijnych pozwala na pewne wnioski ogólne. Polemiki okresu 1419-1471 obejmowały właściwie wszystkie możliwe wówczas formy toczenia sporów. Obok listów o charakterze propagandowym, na które nie spodziewano się odpowiedzi (manifesty), występowała tradycyjna korespondencja, która miejscami przybierała formę traktatów teologicznych. Nie brakowało traktatów sensu stricto, w tym przygotowywanych jako podstawa lub podsumowanie wystąpień publicznych - w czasie soboru czy polemiki przed władcą. Dysponujemy wreszcie jednostronnymi relacjami ze spotkań, na których dyskutowano sprawy ideowe. Kierunki polemik obejmują zarówno oś sporu husycko-katolicką, jak i nie mniej obszerne i emocjonujące debaty między przedstawicielami różnych odłamów reformatorskich. Po pierwszych niepowodzeniach starannie dobierano miejsce i formę dysputy oraz uzgadniano jej zasady z oponentem.

W stosunku do tradycji, zarówno kulturowej jak i kościelnej, dominuje niejednoznaczność i brak konsekwencji. Nie da się wyznaczyć cezury odrzucenia odwołań do tradycji oraz negacji autorytetów. Podstawę do krytyki stanowi jednak przekonanie o działalności Antychrysta, wpływającej zgubnie na Kościół i świat od czasów przełomu konstantyńskiego.

${ }^{31}$ T. A qu in as, Summa Theologica, ed. L. Vives, v. 7, Paris 1859, p. 3, q. 73, art. 3.

${ }^{32}$ Prokop z Pilzna, Defensio communionis sub utraque specie quoad parvulos, facta Basileae, die 31. augusti 1437, Národní knihovna České republiky, VIII.F.22, f. 398v. 
Reformatorzy, zwłaszcza umiarkowanego nurtu, nie stronią od praktyk manipulacyjnych, podfałszowując cytowane teksty lub wyrywając przykłady z kontekstu. Takie praktyki zdarzają się zarówno w dysputach między husytami, jak i w argumentacji utrakwistów wobec soboru.

\section{Bibliografia:}

T. Aquinas, Summa Theologica, ed. L. Vives, v. 7, Paris 1859.

Aristotle, Problems, tt. W. S. Hett, t. 2, London-Cambridge MA 1957.

Der Briefwechsel des Eneas Silvius Piccolomini, v. III, ed. R. Wolkan, Fontes Rerum Austriacarum, Bd. 68, Wien 1918, s. 22-57.

S. Bylina, Na skraju lewicy husyckiej, Warszawa 2005.

P. Cermanová, Jakoubkův a Biskupcưv Výklad na Apokalypsu. Porovnánís důrazem na interpretaci antikristovského mýtu, [w:] Jakoubek ze Střibra. Texty a jejich působeni, ed. O. Halama, P. Soukup, Praha 2006, s. 209-227.

P. Chelčický, O šelmě a obraze jejím, [w:] Čitanka Petra Chelčického, ed. K. J. Obrátil, Brno 1925, s. $107-126$.

P. Chelčický, Tuto se již počíná jíná řeč o šelmě a obraze jejím, [w:] Čítanka Petra Chelčického..., s. $126-129$.

D. Coufal, Polemika o kalich mezi teologii a politikou 1414-1431, Kalich 2012.

P. Čornej, M. Barlová, Velké dějiny zemi Koruny České, t. VI: 1437-1526, Paseka-Praha-Litomysl 2007.

Deník táborského kněze o jednani Čechů na koncilu basilejském z roku 1433, [w:] Ze zpráv a kronik doby husitské, př. F. Heřmanský, ed. I. Hlaváček, Praha 1981, s. 317-419.

Documenta Mag. Joannis Hus, vitam, doctrinam, causam in Constantiensi concilio actam et controversias de religione in Bohemia annis 1403-1415, ed. F. Palacký, Pragae 1869.

T. Fudge, The Trial of Jan Hus. Medieval Heresy and Criminal Procedure, Oxford 2013.

Hilarii Litomericensis, s. Ecclesiae Pragensis decani, Disputatio cum Ioanne Rokyczana coram Georgio, rege Bohemiae, per quinque dies habita anno 1465, ed. B. V. Strahl, Pragae 1775.

J. Hofer, Johannes Kapistran. Ein Leben im Kampf um die Reform der Kirche, t. II, Romae 1964.

J. Hus, O Kościele, tł. K. Moskal, Lublin 2007.

Husitské manifesty, ed. A. Molnár, Praha 1980.

Jakoubek ze Střibra, Výklad na zjevenie sv. Jana, ed. F. Šimek, dil I-II, Praha 1932-1933.

Jan z Borotína, Ottův Slovník Naučný, t. 4, Praha 1891, s. 401.

Jan z Rabštejna, Dialogus, ed. B. Ryba, Praha 1946.

Johannis de Ragusio tractatus quomodo Bohemi reducti sunt ad unitatem Ecclesiae, [w:] Monumenta conciliorum generalium seculi decimi quinti, t. I, ed. F. Palacký, Vindobonae 1857, s. 133-286.

H. Kaminsky, Pius Aeneas among the Taborites, „Church History”, 1959, v. 28, nr 3, s. 281-309.

E. Kantůrkova, Jan Hus, Praha 2008.

P. Kras, Donacja Konstantyna - legenda w stużbie polityki papieskiej, „Studia Mediaevalia Bohemica", 2011, v. 3, nr 1, s. 7-32.

A. Krchňák, Čechové na basilejském sněmu, Svitavy 1997.

P. Libichová Cermanová, Antichristus avarus contra pauperes Christi. Chudoba a jeji vyznam $v$ apokaliptickém diskurzu, [w:] Colloquia mediaevalia Pragnesia, t. VI: Zbožnost středověku, ed. M. Nodl, Praha 2007, s. 111-134.

P. Libichová Cermanová, Gog a Magog: lid z konce světa a věků v husitství, [w:] Zrození mýtu. Dva životy husitské epochy. K počtě Petra Čorneje, ed. R. Novotný, P. Šamal, Paseka-Praha-Litomyšl 2011, s. 230-243. 
A. Lissowska, Antyhusycka misja Jana Kapistrana na Śląsku, [w:] Bernardyni na Śląsku w późnym średniowieczu, red. J. Kostowski, Wrocław 2005, s. 51-63.

Matěj z Janova, Regulae Veteris et Novi Testamenti, sv. 3, ed. V. Kybal, Innsbruck 1911.

A. Michálek, Antikrist - kličové slovo v jazyce doby husitské, „Husitsky Tábor”, 1981, v. 4, s. 110-112.

J. Milíč z Kroměřiža, Spisek o Antikristovi, [w:] Milič z Kroměříže, Poslání papeži Urbanu V. Spisek o Antikristovi, ed. F. Loskot, Praha 1948, s. 18-27.

Milicii Libellus de Antichristo, [w:] Matěj z Janova, Regulae Veteris et Novi Testamenti, sv. 3, ed. V. Kybal, Innsbruck 1911, s. 368-381.

A. Molnár, Chebský soudce, [w:] Soudce smluvenýv Chebu. Sborník přispěvků přednesených na symposiu k 550. výrocí, red. J. Janáček, Cheb 1982, s. 9-35.

P. Nejedlý, K vývoji substantiva Antikrist(us) ve staročeské slovni zásobě, [w:] Zrozeni mýtu..., s. 285-298.

Z. Nejedlý, Prameny k synodám strany pražské a táborské v létech 1441-1444, Praha 1900.

Nicolaus de Lyra, Postilla super totam Bibliam, ks. 5, ed. O. Scotus, Venetia 1488.

F. Palacký, Dějiny národu českého w Čechách a w Morawě dle pưwodních pramenůw, t. IV/1, Praha 1857.

A. Paner, Jan Hus, Kraków 2002.

Prokop z Pilzna, Defensio communionis sub utraque specie quoad parvulos, facta Basileae, die 31. augusti 1437, Národní knihovna České republiky, VIII.F.22, f. 384r-399v.

A. Sedláček, Zmrzlik ze Svojšina, [w:] Ottův Slovník Naučný, t. 27, Praha 1908, s. 653.

Soudce smluvený v Chebu. Sborník př́spěvki̊ prednesených na symposiu k 550. výrocí, red. J. Janáček, Cheb 1982.

Stižný list české a moravské šlechty proti upáleni mistra Jana Husa, red. P. Čornej, A. Knápek, L. Macek, P. Rous, Okrouhlice 2015.

J. Smołucha, Polityka kurii rzymskiej za pontyfikatu Piusa II (1458-1464) wobec Czech i krajów sąsiednich. Z dziejów dyplomacji papieskiej w XV wieku, Kraków 2008.

F. Šmahel, Jan Hus. Život a dilo, Praha 2013.

F. Šmahel, Život a dilo Jeronýma Pražského, Praha 2010.

Traktát Mistra Jana Rokycany o prijiímáni krve (české zpracováni latinského traktátu Contra sex proposiciones frivolas doctorum apostatarum), ed. F. Šimek, Praha 1941.

R. Urbánek, České děkjiny, t. III/2 (Věk poděbradský), Praha 1930.

Vavřinec z Březove, Kronika husitská, [w:] Fontes Rerum Bohemicarum, t. V, ed. J. Goll, Praha 1893, s. 327-534.

G. Voigt, Enea Silvio de 'Piccolomini als Papst Pius der Zweite und sein Zeitalter, Bd. 2, Berlin 1862.

F. Walouch, Žiwotopis swatého Jana Kapistrana, Brno 1858.

I. Wyclif, De Eucharistia tractatus maior, ed. I. Loserth, London 1892.

Paweł F. Nowakowski

\section{The Characteristic Features of Religious Polemics of The Hussite Era - An Outline of the Issue}

Summary

The aim of the paper is to outline the characteristic features of religious polemics, held during the Hussite era, i.e. in the years 1419-1471. The forms of polemics, from direct correspondence to treaties, were presented in the article. Special attention was devoted to the specific motives that 
weren't the direct object of the polemics, but shaped their rhetoric and determined the field of interpretation. They include the attitude towards cultural and ecclesial tradition, the concept of the Antichrist etc. Finally, examples of manipulation of quotes that were used in the argumentation, from taking words out of context to forgery, were presented.

Key words: religious polemics, Hussitism, the Antichrist, text manipulation 